\title{
The Very Rev. John Harry Miller, C.B.E., T.D., D.D.
}

IN a Society largely representative of the sciences Dr Miller might well be regarded as an expert in the comparatively recent science of Sociology. To that profoundly important and increasingly influential study the Providence that shapes our ends led him by way of a happy ministry in the holiday resort of Elie, where he evinced a brotherly interest in the young folks who thronged its golf course in summer, a varied experience which afterwards bore rich fruit in religious work amongst schoolboys and University students in colleges, camps, and conferences, in England as well as in Scotland. Transferred to a city ministry at Roseburn Church, Edinburgh, he was thence called to an office of which he was the first occupant, the Wardenship of the New College Settlement in the Pleasance, with which ten years later he combined the arduous ministry of the Pleasance Church. At last he had found his true métier. Under his guidance the mission became a clinic in the technique of social work for the students of New College. The premises at that time were very inadequate for the work urgently demanding to be done, of which he took the broadest view. Soon he had devised elaborate plans of development such as might have staggered any nature less buoyant and resolute than his. Neighbouring properties were gradually acquired, including a derelict brewery, whose possibilities had been perceived by earlier leaders in the Mission, who lacked, however, the wherewithal to realise them. That was left to the Warden. With his magnetic nature, his gay and genial temperament, his diplomatic and persuasive tongue, his infectious and irrepressible enthusiasm, he gathered round him a devoted band of sympathetic and generous friends, and with their hearty support he gained the satisfaction of achieving in large measure the fulfilment of his haunting dreams. A Trust was formed which raised the funds, amounting to several thousand pounds, necessary for transforming the acquired properties into buildings containing rooms and halls, big and small, suitable for all kinds of clubs and meetings, culminating in the Little Theatre with its up-to-date accessories, a spacious gymnasium with an elaborate equipment, and a Health Centre and Orthopædic Clinic with furnishings for sun-ray treatment.

This splendid hive of varied social activities, consecrated to the spiritual uplift of the demoralised locality, won the compliment of a royal visit, when 
King George and Queen Mary expressed an admiration not unmixed with astonishment at the scientific completeness and fitness of its arrangements. The Warden had indeed reason to be proud of his handiwork, for perhaps no one but he, with his peculiar endowments of mind and character, his wide and influential connections, his tireless energies, could have executed an undertaking on such an ambitious scale. In the practical work carried on by the students under his superintendence he was always the leader, who not merely directed but showed the way, constantly engaging in making contacts with the people in their miserable dwellings, trying in his own brotherly and humoursome manner to inspire with new desires and aspirations minds and hearts dulled to very deadness by the gloom and hardship of their starved and dismal lot. Opportunity to pass on the accumulated and pondered results of that intimate experience, and of his eager and wide study of appertaining literature, offered itself when in 1922 he was appointed the first Lecturer on Sociology to the students of New College.

After twenty-seven years of ungrudging labour in this exacting sphere, which at last undermined his health and strength, he passed to the quietness of St Andrews, where in 1935 his career was crowned by his appointment as Principal of St Mary's College. But surely he will most of all be remembered as an outstanding pioneer in social work, who left in the Pleasance Settlement and Mission a monument to his constructive imagination, his fervent Christian idealism, his largeness of heart, which ever sought to make life worth living for the denizens of habitations so destructive of the best in human nature.

He was a late-comer into the list of the Society's membership, having been elected a Fellow only in 1936. But his name, especially in view of his fine achievements as a practical exponent of Social Science, may well adorn its roll. He died on January 3, 1940.

A. M. H. 